\title{
Ribulose bisphosphate carboxylase gene expression in subtropical marine phytoplankton populations
}

\author{
Scott L. Pichard, Marc E. Frischer, John H. Paul* \\ Department of Marine Science, University of South Florida, St. Petersburg, Florida 33701, USA
}

\begin{abstract}
Oceanic phytoplankton are known to fix $\mathrm{CO}_{2}$ primarily through the action of the enzyme ribulose-1,5-bisphosphate carboxylase (RuBPCase). The amino acid and nucleotide sequence of the large subunit of this enzyme have been conserved across the evolution of the chlorophytic plants (from cyanobacteria to higher plants via green algae) with approximately 80 and $70 \%$ homology at the amino acid and nucleotide levels respectively. To understand the molecular regulation of this enzyme in phytoplankton, we have measured levels of the RuBPCase large subunit $(r b c L)$ mRNA and DNA, in combination with rates of photosynthetic $\mathrm{CO}_{2}$ fixation, autofluorescent cell counts, and chlorophyll $a$ in natural phytoplankton communities of Tampa Bay (Florida, USA) and the southeastern Gulf of Mexico. We measured $r b c L$ mRNA, $r b c L$ DNA, and the ratio of $r b c L$ mRNA to $r b c L$ DNA by extracting RNA and DNA and probing the extracts with the Synechococcus PCC 6301 rbcL gene as a probe. Additionally, $r b c L$ mRNA was amplified from certain samples using a reverse transcriptase-linked polymerase chain reaction procedure. In a transect from Tampa Bay seaward, levels of $r b c L$ mRNA decreased 3- to 8-fold from the estuarine environment to the of fshore environment, and followed similar trends as photosynthetic $\mathrm{CO}_{2}$ fixation, picocyanobacterial counts, and chlorophyll a. In an offshore vertical profile, the subsurface maximum in the $I b c L$ mRNA/DNA ratio coincided with the 60 m maximum in photosynthetic assimilation rates. In a diel study using $150 \mathrm{l}$ of offshore water in a deck-top incubator, the $r b c L$ mRNA/DNA ratio was nearly an order of magnitude greater ( $76 \mathrm{ng}$ mRNA ng ${ }^{-1}$ DNA) during the light period than in the dark (17 ng mRNA $\mathrm{ng}^{-1}$ DNA). Likewise, the photosynthetic rate $\left(P^{\mathrm{B}}\right)$ at constant illumination was highest during daylight hours $\left(6.2 \mu \mathrm{g} \mathrm{C} \mu \mathrm{g}^{-1} \mathrm{chl} a \mathrm{~h}^{-1}\right)$ and lowest at night $(1.9 \mu \mathrm{g} \mathrm{C}$ $\mu \mathrm{g}^{-1} \mathrm{chl} \mathrm{a} \mathrm{h}^{-1}$. These results indicate that (1) carbon fixation in oceanic phytoplankton may be transcriptionally regulated at the level of the RuBPCase gene and (2) that the quantitation of particular target mRNAs and DNAs is an effective means to study the regulation of conserved gene functions in natural water column microbial populations.
\end{abstract}

\section{INTRODUCTION}

The enzyme ribulose-1,5-bisphosphate carboxylase/ oxygenase (E.C. 4.1.1.39, RuBPCase) is the major carboxylating enzyme in the phytoplankton of the world's oceans (Descolas-Gros \& Fontugne 1985, Beardall 1989, Colman 1989). Knowledge of the in situ regulation of this enzyme will improve our understanding of the mechanisms controlling primary production in the oceans.

\footnotetext{
- Addressee for correspondence
}

In all phytoplankton and multicellular plants, RuBPCase exists as a multimeric enzyme comprised of large and small subunits in equal proportion (L8S8). The large subunit, which contains the activation and catalytic site, has been conserved across the evolution of the 'green' plants (cyanobacteria to higher plants). For example, a comparison of cyanobacteria, prochlorophyte, green algae and higher plant RuBPCase large subunits indicated an $85.7 \pm 3.7 \%$ similarity at the amino acid level and a $75 \pm 4.9 \%$ similarity at the nucleotide level for the $r b c L$ genes (Morden \& Golden 1991). Red algae, cryptophytes, diatoms and Ochromonas sp. represent a different evolutionary lineage in 
terms of RuBPCase large subunits. Within this group RuBPCase is approximately $85 \%$ similar at the amino acid level, but only $55 \%$ similar to cyanobacteria, green algae and higher plants (Newman \& Cattolico 1987, Douglas et al. 1990, Kostrzewa et al. 1990, Hwang \& Tabita 1991). While diatoms, dinoflagellates, cryptomonads, and other 'non-green' algae are present in offshore marine waters (Vargo 1984, Siegel et al. 1990), the most abundant phytoplankters in the oligotrophic ocean are the 'green' lineage-type picophytoplankton (Waterbury et al. 1986). These Synechococcus-like picoplankton $\left(10^{3}\right.$ to $10^{4}$ cells $\left.\mathrm{ml}^{-1}\right)$ and free-living prochlorophytes (up to $10^{5}$ cells $\mathrm{ml}^{-1}$ ) are responsible for up to $80 \%$ of the water column primary production (Takahashi \& Hori 1984, Itturiaga \& Mitchell 1986, Chisholm et al. 1988),

A variety of methods have been used to study the relationship between RuBPCase activity and photosynthesis. Laboratory studies with marine phytoplankton in unialgal culture show a positive correlation between light-saturated photosynthesis $\left(P_{\max }\right)$ and in vitro RuBPCase activity. However, studies of natural populations have found that $P_{\max }$ and RuBPCase were not always as tightly coupled as in culture (Glover \& Morris 1979, Smith et al. 1983). Increases in $P_{\max }$ were associated with increases in RuBPCase and not phosphoenolpyruvate carboxylase (PEPCase) activity. Immunological probes for phytoplankton RuBPCase

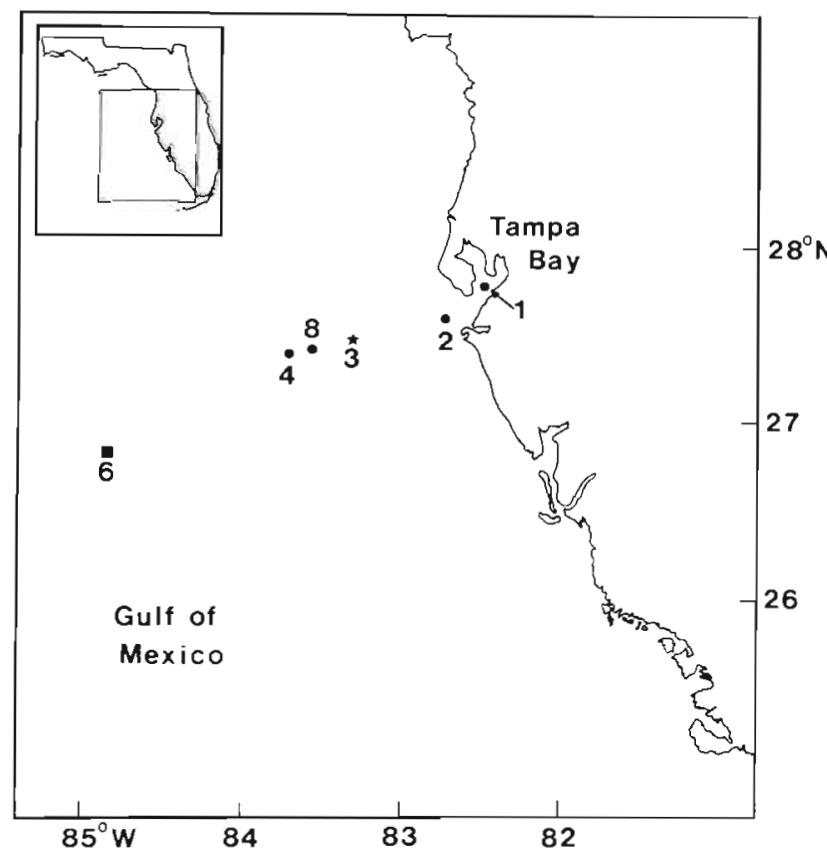

Fig. 1. Locations for stations sampled for $r b c L$ mRNA. Stn 3 (*) was the location of sampling for a diel study. Stn 6 (a) was the location for sampling $r b c L$ expression as a function of depth in the euphotic zone have been applied to assess the RuBPCase concentration in individual phytoplankton cells and have shown a correlation of RuBPCase concentration with the light-saturated rates of photosynthesis for a range of laboratory-cultured phytoplankton taxa (Orellana \& Perry 1992).

Phytoplankton are considered physiologically adaptable organisms, being able to acclimate to rapidly changing environmental conditions (Falkowski \& LaRoche 1991). However, little is known about the molecular mehanisms responsible for these adaptive responses. We have previously presented evidence that levels of $r b c L$ transcripts exhibit diel variation for natural phytoplankton populations in oligotrophic waters (Pichard \& Paul 1991). The objective of the present study was to quantify the relationship between $\mathrm{rbcL}$ transcripts, rbcL DNA levels and rates of carbon fixation for marine phytoplankton over a range of environmental conditions

\section{MATERIALS AND METHODS}

Culture conditions. Synechococcus sp. PCC 6301 was grown in BG-11 medium (Cote 1984) at 300 to $600 \mu \mathrm{E} \mathrm{m}^{-2} \mathrm{~s}^{-1}$ (cool white light) 12:12 h light/dark cycle and 22 to $25^{\circ} \mathrm{C}$.

Sampling procedures. Samples were collected at both Tampa Bay (Florida, USA) and Gulf of Mexico stations shown in Fig. 1 as well as a single station located near Joulters Cay, Bahamas $\left(25^{\circ} 19.07^{\prime} \mathrm{N}\right.$, $78^{\circ} 05.33^{\prime} \mathrm{W}$ ). Various subsurface (1 to $5 \mathrm{~m}$ depth) sample volumes were collected using a submersible pump lowered over the side of the ship to fill acidwashed 201 carboys. For the Gulf of Mexico diel study (Stn 3), seawater from $3 \mathrm{~m}$ was pumped into a $200 \mathrm{l}$ polyethylene on-deck incubator and 2 layers of neutral density screening were placed over the top to reduce surface illumination. The temperature in the tank was controlled $\left(29.5^{\circ} \mathrm{C}\right)$ by use of a Coolflow refrigerated recirculator CFT-33 (NESLAB Instruments, Inc., Portsmouth, NH, USA) and tygon tubing. Recent studies have successfully employed large on-deck incubators to study phytoplankton physiology under simulated in situ conditions (Prezelin et al. 1987, Wilkerson \& Dugdale 1987, Legendre et al. 1988).

RNA/DNA determinations. For each water sample, both RNA and DNA measurements were performed in duplicate. Samples were pretreated by addition of diethylpyrocarbonate (DEPC; Sigma Chemical Co., St. Louis, MO, USA) at $0.1 \%$ to minimize nuclease activity and then filtered onto Durapore filters $(25 \mathrm{~mm}$, $0.45 \mu \mathrm{m}$; Millipore Corporation, Bedford, MA, USA). Volumes filtered were $100 \mathrm{ml}$ for eutrophic waters and $300 \mathrm{ml}$ for oligotrophic waters. For the station near 
Joulters Cay, 2 I samples were filtered through Whatman GF/F filters as described by Pichard \& Paul (1991). Whatman GF/F filters were baked at $450^{\circ} \mathrm{C}$ for $4 \mathrm{~h}$ and Durapore filters were autoclaved prior to use. All extractions were performed as in Pichard \& Paul (1993). In brief, filtered samples were extracted for RNA by placing the filters into sterile $2.2 \mathrm{ml}$ bead-beater microcentrifuge tubes (Biospec Products, Bartlesville, OK, USA) containing $0.5 \mathrm{ml}$ extraction reagent ( $4 \mathrm{M}$ guanidinium thiocyanate, $0.5 \%$ sarcosyl, $25 \mathrm{mM}$ sodium citrate $\mathrm{pH} 7.0$, and $0.1 \mathrm{M}$ 2-mercaptoethanol). To each tube $0.5 \mathrm{ml}$ of water-saturated phenol, $50 \mu \mathrm{l}$ of $2 \mathrm{M}$ sodium acetate $\mathrm{pH} 4.0,100 \mu \mathrm{l}$ of chloroform-isoamyl alcohol (49:1), and $0.5 \mathrm{~g}$ glass beads (diameter: 0.1 to $0.15 \mathrm{~mm}$; Biospec Products) were added. The filters were extracted by beating the tubes for 2 min using a mini-beadbeater (Biospec Products), cooled on ice for $15 \mathrm{~min}$, and then centrifuged in a microcentrifuge for $5 \mathrm{~min}$. The aqueous supernatant was removed and the filters extracted 2 more times as above. The aqueous supernatants were combined and the RNA precipitated with 1 volume of isopropanol for $2 \mathrm{~h}$ at $-20^{\circ} \mathrm{C}$. The RNA was collected by centrifugation in a microcentrifuge for $10 \mathrm{~min}$ and redissolved in DEPC-treated $1 \mathrm{mM}$ EDTA pH 7.0. Samples were reprecipitated overnight at $-20^{\circ} \mathrm{C}$ in 0.1 volume $2 \mathrm{M}$ sodium chloride, 2 volumes of $100 \%$ ethanol with $20 \mu \mathrm{g}$ glycogen. The RNA was again collected by centrifugation, washed once with 1 volume of ice-cold $70 \%$ ethanol and resuspended in DEPC-treated EDTA.

DNA extractions were performed by adding the filter to $1 \mathrm{ml}$ sterile STE pH 8.0 (Sambrook et al. 1989) in $2.2 \mathrm{ml}$ bead beater tubes, then adding $100 \mu 110 \%$ SDS and placing the sample in boiling water for $2 \mathrm{~min}$. After cooling, cell debris was removed by a 10 min centrifugation and the supernatant collected. The pellet was reextracted as above and the combined supernatants precipitated with 0.1 volume $3 \mathrm{M}$ sodium acetate $\mathrm{pH} 5.0$, and 2 volumes $100 \%$ ethanol at $-20^{\circ} \mathrm{C}$ overnight. The DNA was collected by a $10 \mathrm{~min}$ centrifugation and the pellet washed with 1 volume of icecold $70 \%$ ethanol. The DNA was resuspended in DEPC-treated sterile deionized water. Nucleic acid extracts (RNA and DNA) were subjected to RNase and DNase enzyme treatments as in Pichard \& Paul (1991). Samples were then dot-blotted onto charged nylon (Zetaprobe; BioRad, Richmond, CA, USA) and baked in a vacuum oven at $80^{\circ} \mathrm{C}$ for $2 \mathrm{~h}$. Detection and quantification of $r b c L$ mRNA and DNA was performed by hybridizing $r b c L$ RNA gene probes to target RNA and DNA as previously described (Pichard \& Paul 1991, 1993). A sample from Stn 8 was also probed with a probe for a gene not expected to be found in oceanic samples, the catechol dioxygenase gene (xylE) of the TOL plasmid, as previously described (Pichard \& Paul
1993). Sample RNA and DNA signals were compared to signals obtained from standard curves by $\beta$-counting as in Pichard \& Paul (1993).

Phytoplankton carbon fixation. Rates of carbon fixaton were measured by the ${ }^{14} \mathrm{C}_{-} \mathrm{HCO}_{3}{ }^{-}$technique as outlined by Strickland \& Parsons (1968) and modified by Carpenter \& Lively (1980). Samples (325 ml) were placed in sterile $500 \mathrm{ml}$ acid-washed Polycarbonate bottles. Light and dark bottle incubations were used to determine light dependent rates of carbon fixation. Light bottle values were corrected by subtracting dark bottle values. Radioactive bicarbonate, $\left[{ }^{14} \mathrm{C} \mathrm{HCO}_{3}{ }^{-}\right.$ (53.1 $\mathrm{mCi} \mathrm{mmol}^{-1}$; Amersham Corporation, Arlington Heights, IL, USA), was added to each light and dark bottle to a final radioactivity of $0.5 \mu \mathrm{Ci} \mathrm{ml} \mathrm{m}^{-1}$. A zerotime point sample was taken by filtration through a Millipore GS $0.2 \mu \mathrm{m}$ filter and both light and dark bottles were incubated under constant white light illumination (ca $500 \mu \mathrm{E} \mathrm{m}^{-2} \mathrm{~s}^{-1}$ ). Duplicate samples were taken at 1 and $2 \mathrm{~h}$. Filters were added to glass scintillation vials containing $0.5 \mathrm{ml}$ of $0.5 \mathrm{~N} \mathrm{HCl}$ and incubated overnight at room temperature. Sample radioactivity was determined by dissolving the filter in ethyl acetate, adding $10 \mathrm{ml}$ of a scintillation cocktail (Ecoscint $\mathrm{A}_{\text {; }}$ National Diagnostics, Manville, IL), and liquid scintillation counting using a Delta 300 model 6891 liquid scintillation counting system (TM Analytic, Inc., Elk Grove Village, IL). Counting efficiency was determined by scintillation counting of $a{ }^{14} \mathrm{C}$ standard (Wang et al 1975).

Water samples were titrated by the method of Strickland \& Parsons (1968) to determine cabonate alkalinity and total $\mathrm{CO}_{2}$ content. The total sample $\mathrm{CO}_{2}$ content and incorporated ${ }^{14} \mathrm{C}$ were used to determine the rate of carbon fixation for each water sample.

Chlorophyll $a$ and autotrophic cell counts. Samples for chlorophyll a (chl a) were filtered in triplicate through Whatman GF/F filters and the filters stored at $-20^{\circ} \mathrm{C}$ until analysis. Chl a was methanol extracted and quantified fluorometrically (Holm-Hansen \& Reimann 1978). Autofluorescent picoplankton (orangeyellow) and red fluorescing cells were enumerated by the method of Vernet et al. (1990). Cells were filtered onto irgalan black-stained $0.2 \mu \mathrm{m}$ Nuclepore filters in duplicate. The filter was then placed onto a microscope slide, a drop of $100 \%$ glycerol was place between the filter and the cover slip, and the slide stored in the dark at $-20^{\circ} \mathrm{C}$. Cells were enumerated using blue light excitation $(450 \mathrm{~nm})$ and $400 \times$ magnification with an Olympus BH-2 epifluorescence microscope.

Messenger RNA (mRNA) amplification. $r b c L$ mRNA was amplified from RNA extracts from Bayboro Harbor and from Synechococcus sp. PCC6301 culture using the method of Becker-Andre \& Hahlbrock (1989) and degenerate oligonucleotide primers for conserved por- 
tions of the $r b c L$ gene linked to restriction sites. The $5^{\prime}$ or 'left' primer sequence was TGGATCCTAC(GCA) (AG)T(TC)AAACC(AT)AAA(CT)T(CA)GGTCTG and the 3' or 'right' primer was TGAATTCT(CA)(CA)(TG) (TA)GC(AG)CCGTC(GT)A(TA)GTG(CTA)AG. mRNA was first converted to DNA using the following reaction mixtures: $50 \mathrm{mM}$ Tris- $\mathrm{HCl} \mathrm{pH} 7.5,75 \mathrm{mM} \mathrm{KCl}, 10$ $\mathrm{mM}$ Dithiothreitol, $3 \mathrm{mM} \mathrm{MgCl}_{2}, 100 \mathrm{ng}$ 3'primer, and $0.5 \mathrm{mM}$ each of the deoxynucleotide triphosphates (dNTPs) in a total volume of $20 \mu 1$. The reaction mix was heated to $65^{\circ} \mathrm{C}$ for $5 \mathrm{~min}$ and then cooled to room temperature. RNasin ( 6 units; Promega Corporation, Madison, WI, USA) and reverse transcriptase (RT; 40 units; Life Sciences, Inc., St. Petersburg, FL) were added, and the reaction continued for $30 \mathrm{~min}$ at $42^{\circ} \mathrm{C}$. The reaction volume was then made to $100 \mu$ l by addition of $80 \mu$ l of TE pH 8.0 (Sambrook et al. 1989). The DNA was then amplified by the polymerase chain reaction (PCR). For PCR $3 \mu \mathrm{l}$ of DEPC-treated water and $2 \mu \mathrm{l}$ of the reverse transcriptase reaction was added to $94.5 \mu \mathrm{l}$ of PCR buffer containing $50 \mathrm{mM} \mathrm{KCl}, 10 \mathrm{mM}$ Tris- $\mathrm{HCl} \mathrm{pH} \mathrm{8.3,15} \mathrm{mM} \mathrm{MgCl} 2,0.01 \%$ gelatin, $200 \mu \mathrm{M}$ of each dNTP, and $1 \mu \mathrm{M}$ each of $3^{\prime}$ and $5^{\prime}$ primer.
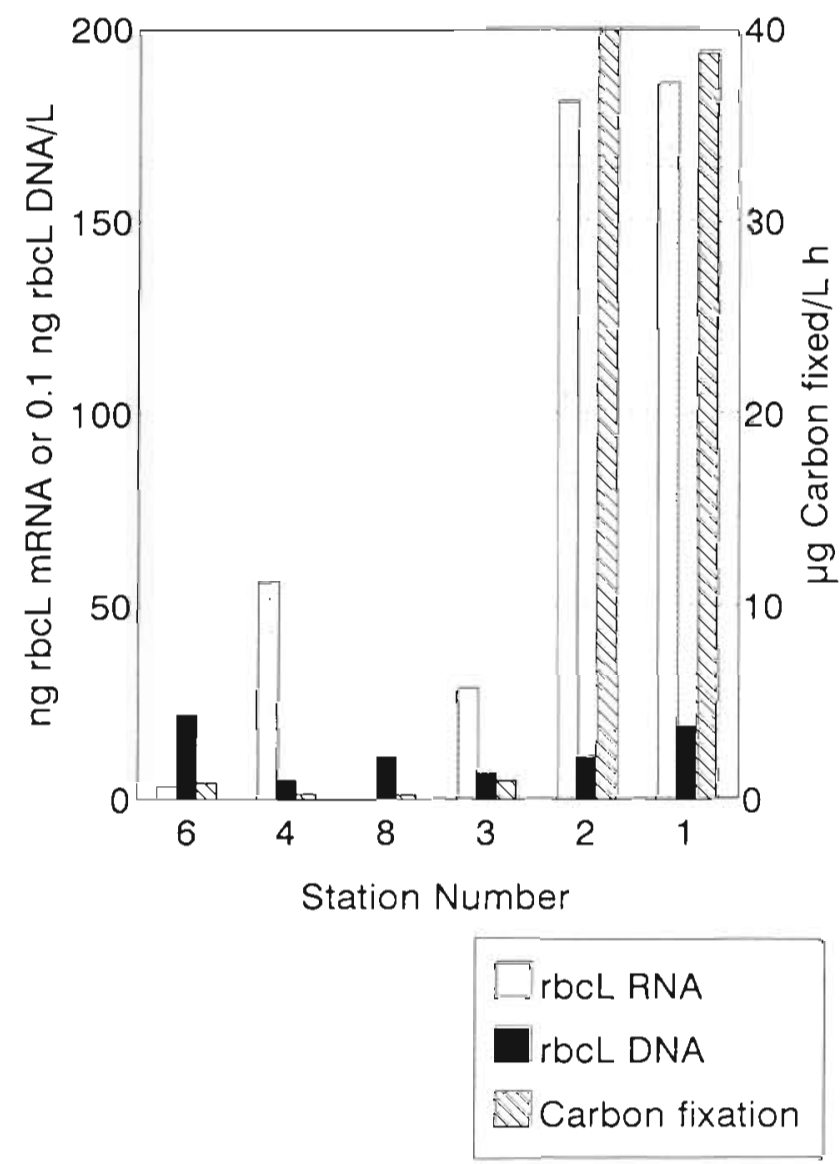

Fig. 2. Concentrations of $r b c L$ mRNA, DNA, and carbon fixation for stations indicated in Fig. 1
Reaction mixtures were vortexed and brielfly centrifuged. One-half microliter ( 3 units) of Taq polymerase (Promega) was added, and the reaction was mixed by vortexing, and centrifuged again. Samples were overlain with $100 \mu \mathrm{l}$ of sterile mineral oil and the samples amplified for 39 cycles using the following temperature regime: (1) $1 \mathrm{~min}$ at $94^{\circ} \mathrm{C}$, (2) 2 min at $50^{\circ} \mathrm{C}$ and (3) 3 min at $72^{\circ} \mathrm{C}$. PCR reactions were electrophoresed on $1 \%$ agarose and stained with Hoechst 33258 (Deflaun \& Paul 1986). The DNA was transferred to a charged nylon membrane (Sambrook et al. 1989) and probed with the $r b c L$ gene probe for confirmation of amplification products.

Data analysis. Regression analysis (Zar 1984) was used to determine $r b c L$ RNA and DNA concentrations from standard curves.

\section{RESULTS}

The results of sampling of surface waters at stations in the Gulf of Mexico along a nearshore-offshore transect for $r b c L$ mRNA and DNA, chl $a$, carbon fixation and autofluorescent cell counts appear in Figs. 2, 3 \& 4 respectively. A sample was also collected at the offshore Stn 8 and probed for the expression of the catechol dioxygenase gene (xylE) as a control for nonspecific hybridization as in Pichard \& Paul (1993). No xylE hybridization was found with RNA extracts from this station (data not shown). rbcL mRNA concentrations ranged from 185.8 to $0.2 \mathrm{ng} \mathrm{l}^{-1}$, with highest values in nearshore waters, lowest in offshore waters (Fig. 2). Carbon fixation showed a similar trend and was highly correlated with the $r b c L$ mRNA concentrations $(\mathrm{r}=0.97$; Fig. 2A). Carbon fixation/chl $a$ and $r b c L$ mRNA/DNA were similar in the estuarine stations but apparently varied independently at the oceanic stations in the transect (Stns 3 to 8), yielding an overall correlation coefficient of $\mathrm{r}=0.74$ (Fig. 3). Orange-fluorescing picoplankton counts (presumably Synechococcus-like cyanobacteria; Fig. 4) were greatest in nearshore waters $\left(6.78 \pm 0.21 \times 10^{4}\right.$ cells ml $\left.^{-1}\right)$ and decreased in offshore oligotrophic waters $15.35 \pm$ $1.48 \times 10^{3}$ cells $\mathrm{ml}^{-1}$ ). Similarly, the red fluorescing cells (presumably eucaryotic picoplankton and nonPE-containing cyanobacteria) were also most abundant in nearshore waters ranging from $1.39 \pm 0.18 \times$ $10^{3}$ cells $\mathrm{ml}^{-1}$ at the mouth of Tampa Bay to 38 cells $\mathrm{ml}^{-1}$ for offshore samples. Chl a decreased by more than an order of magnitude, ranging from $8.43 \mu \mathrm{g} \mathrm{chl}$ $a \mathrm{I}^{-1}$ in Tampa Bay to $0.072 \mu \mathrm{g} \mathrm{chl} \mathrm{a} \mathrm{l}^{-1}$ in the Gulf of Mexico, declining most rapidly at the transition from estuarine to coastal waters. However, while chl a varied by more than an order of magnitude, rbcL DNA (Fig. 2, an independent measure of photosynthetic 


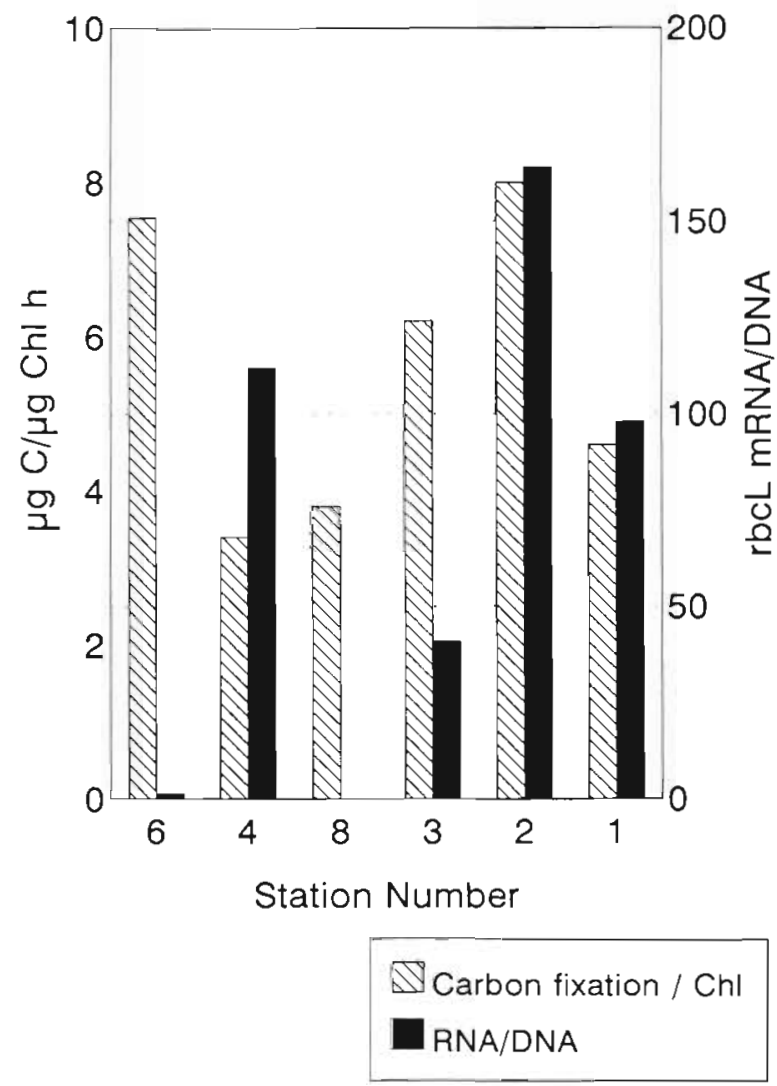

Fig. 3. Values for the normalized parameters $P^{B}$ (carbon fixation/chl a) and $r b c L$ gene expression per gene dose (rbcL mRNA/DNA) at the stations indicated in Fig. 1

biomass) only changed from 2.0 to $0.5 \mathrm{ng} \mathrm{l}^{-1}$ between nearshore and offshore environments with 1 offshore sample (Stn 6) having a greater DNA content than the nearshore station. To evaluate the DNA content of the phytoplankton sampled $r b c L$ DNA was transformed to copies of $r b c L$ based upon the $1500 \mathrm{bp}$ size of the $r b c L$ gene. The rbcL copies were then converted to equivalent genome copies assuming 1 copy of $r b c L$ per genome. The number of $r b c L$ genomes ranged from $1.33 \times 10^{9} \mathrm{I}^{-1}$ at $\operatorname{Stn} 6$ to $3 \times 10^{8} \mathrm{I}^{-1}$ at Stn 4 . The average for all stations in this data set was $7.8 \pm 4.0 \times$ $10^{8} \mathrm{l}^{-1}$. When taking into account the autofluorescent cells present, the $r b c L$ gene content per picoplankton cell ranged from 15.7 (Stn 1) to 138 (Stn 6). These results suggest that either oceanic phytoplankton contain multiple copies of the $r b c L$ gene or that we have underestimated the abundance of the autotrophic cells present. We may have missed the prochlorophyte component of the population because these forms are difficult to detect by epifluorescence microscopy (Chisholm 1992), yet we would expect to detect their rbcL DNA by molecular probing.

The relationship between autotrophic biomass, autotrophic cell counts, carbon fixation, and $r b c L$ mRNA
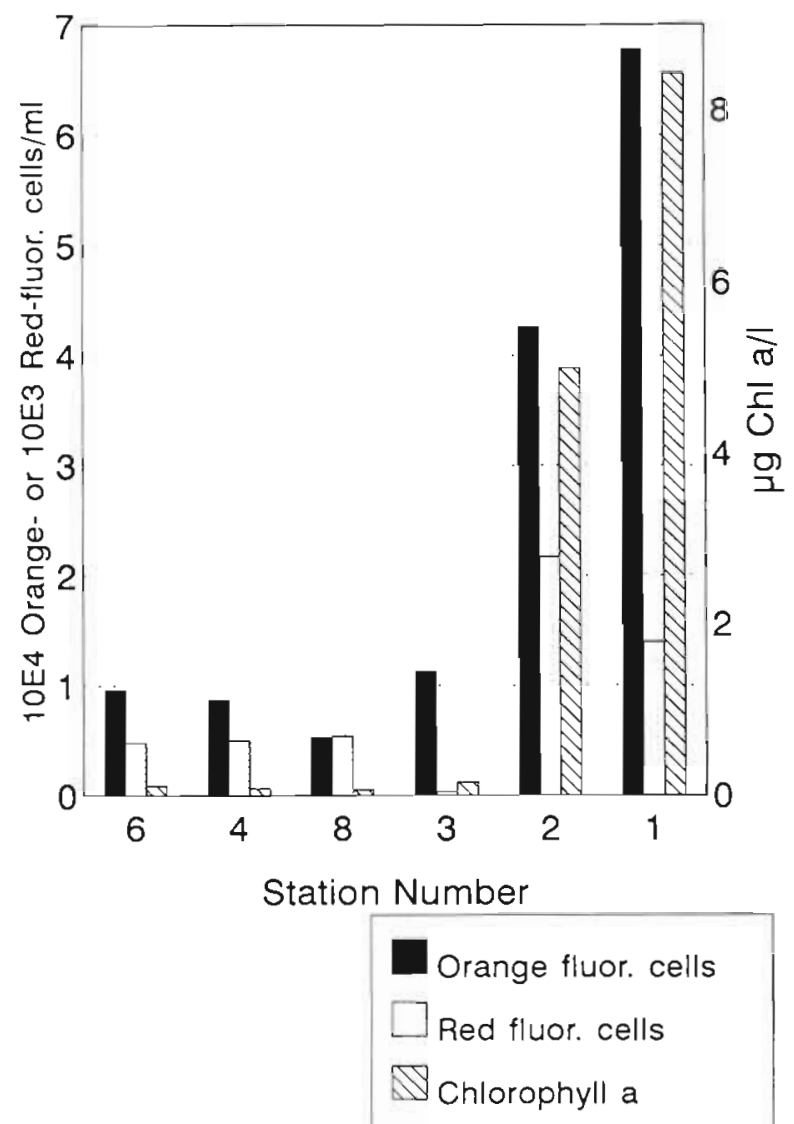

Fig. 4. Autotrophic population size as estimated by chl $a$ and autofluorescent cell counts for the stations indicated in Fig. 1

and DNA was also investigated in a vertical profile at the offshore $\operatorname{Stn} 6$. Dot blots of both $r b c L$ mRNA and DNA are shown in Fig. 5 with the results of quantification appearing in Fig. 6. The rbcL DNA concentrations decreased with depth to minimal levels between 60 and $100 \mathrm{~m}$. In contrast, $r b c L$ mRNA concentrations increased from $10 \mathrm{~m}$ to a peak at $30 \mathrm{~m}$ below which levels declined linearly to $100 \mathrm{~m}$ (Fig. 6). Carbon fixa-

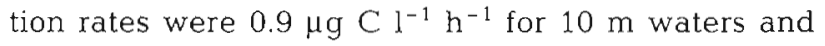
exhibited a subsurface peak at $60 \mathrm{~m}$ that was half of the $10 \mathrm{~m}$ value. Carbon fixation per chl $a\left(P^{\mathrm{B}}\right)$ and $r b c L$ mRNA/DNA exhibited similar profiles below $30 \mathrm{~m}$ (Fig. 6D). Thus, the vertical distribution of $r b c L$ gene expression per gene dose was similar to that of $P^{\mathrm{B}}$.

Autofluorescent picoplankton cells were most abundant in surface waters while red cells increased as a function of depth, with a maximum $(1.19 \pm 0.34 \times$ $10^{3}$ cells $\mathrm{ml}^{-1}$ ) at the deepest depth sampled $(100 \mathrm{~m})$. This increase in red cells with depth was reflected in an increase in chlorophyll concentrations at $100 \mathrm{~m}$ relative to the surface. As was found for $r b c L$ DNA in the stations in the transect, $r b c L$ DNA content per picoplankton cell exceeds the $r b c L$ DNA content for these type organisms. This suggests that the measured 


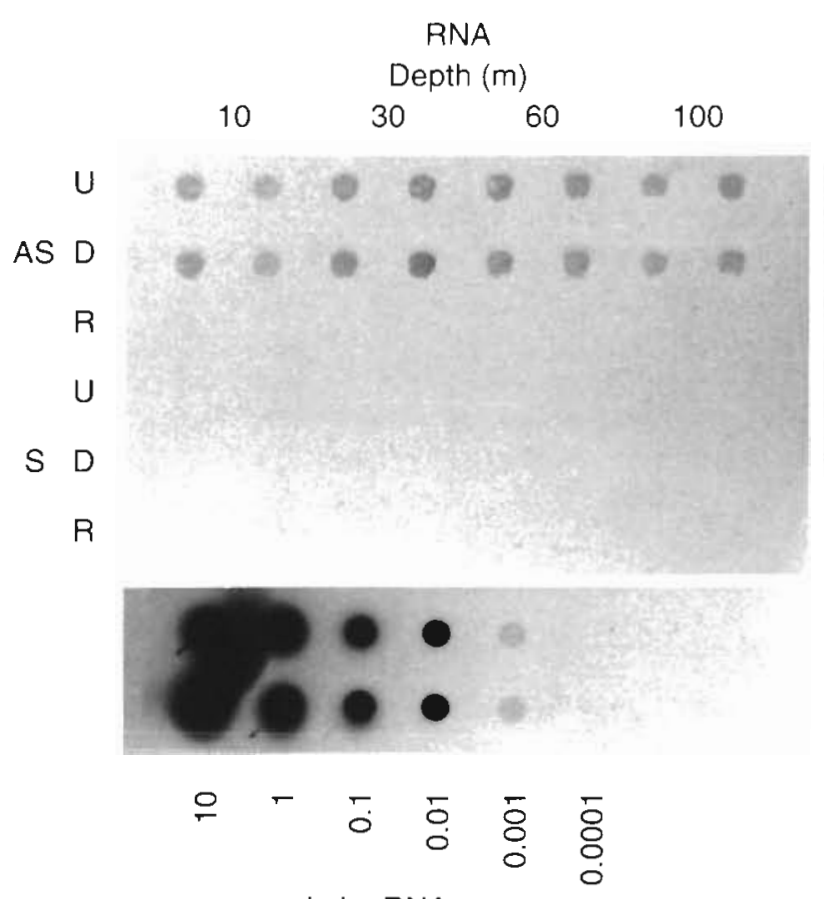

ng rbcl mRNA

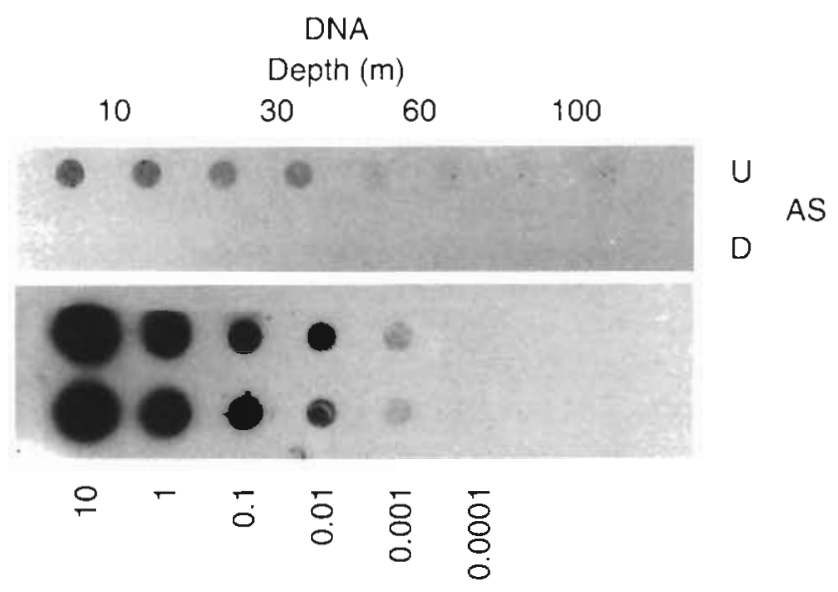

ng rbcl mRNA

Fig. 5. Autoradiograph of dot blots of $r b c L$ mRNA and DNA from $300 \mathrm{ml}$ samples of seawater at Stn 6 . Vertical profiles of the natural population mRNA and DNA are shown as well as $r b c L$ mRNA and DNA standard curves used for quantifying RNA and DNA levels. U: untreated; D: DNase treated; R: RNase treated; AS: antisense probe; $S$ : sense probe

rbcL DNA was contributed by phytoplankton other than Synechococcus present in the samples.

To determine if the diel periodicity in phytoplankton carbon fixation (Doty \& Oguri 1957) might be the result of transcriptional regulation of $r b c L$, we measured $r b c L$ mRNA and DNA in a water mass maintained in a deck-top incubator. Both carbon fixation and mRNA (Fig. 7) were elevated by a factor of 5 during daylight hours compared to the night hours, while chl $a$ and $r b c L$ DNA remained constant. Specific levels of $r b c L$ gene expression ( $r b c L$ mRNA/DNA) correlated with $P^{\mathrm{B}}(\mathrm{r}=0.96)$. This suggests that diel changes in carbon fixation are regulated by changes in transcription of the rbcL genes for the phytoplankton populations sampled.

Fig. 8 shows the results of a diel study of carbon fixation, $r b c L$ mRNA, and chl a for a phytoplankton population in Bahamian surface waters. Unlike the previous diel study, the surface waters were sampled over $48 \mathrm{~h}$ from the same location and not for an enclosed water mass in a decktop incubator, and $r b c L$ DNA was not measured. Extracted RNA resulted in material that hybridized to the antisense (AS) $r b c L$ gene probe (Pichard \& Paul 1991) and was digestable by RNase. The strongest hybridization occurred during the daylight hours and the weakest occurred at night, with the exception that a noon sample had the lowest hybridization intensity of $r b c L$ mRNA. Rates of carbon fixation exhibited a similar diel trend as the $r b c L$ mRNA. However, surface chl a also followed this same pattern suggesting that, in this case, carbon fixation and mRNA levels were a function of possible diel variations in phytoplankton abundance.

Amplification of the $r b c L$ mRNA was performed as described and gel electrophoresis of amplification products is presented in Fig. 9A. Amplification of control $r b c L$ mRNA, $r b c L$ DNA, RNA samples from Bayboro Harbor (Stn 1), and RNA from a Synechococcus sp. PCC 6301 culture resulted in a 376 bp segment of the rbcL gene as determined by hybrdization with the $r b c L$ probe (Fig. 9B). Both RNA from Gulf of Mexico Stn 8 as well as stored RNA samples, that previously amplified, were found not to amplify after storage (data not shown) possibly because of the lability of the RNA. All amplifications for greater than 30 cycles resulted in the formation of primer-oligomers (Gelfand \& White 1990).

\section{DISCUSSION}

By using an efficient means of recovering RNA and DNA, we have shown that levels of $r b c L$ mRNA directly correlated with rates of carbon fixation for a range of marine environments (oligotrophic, mesotrophic, and eutrophic). To our knowledge, this is the first evidence for transcriptional regulation of RuBPCase in oceanic phytoplankton communities.

The level of hybridizable $r b c L$ mRNA detected may be an underestimation of the total amount of $r b c L$ 

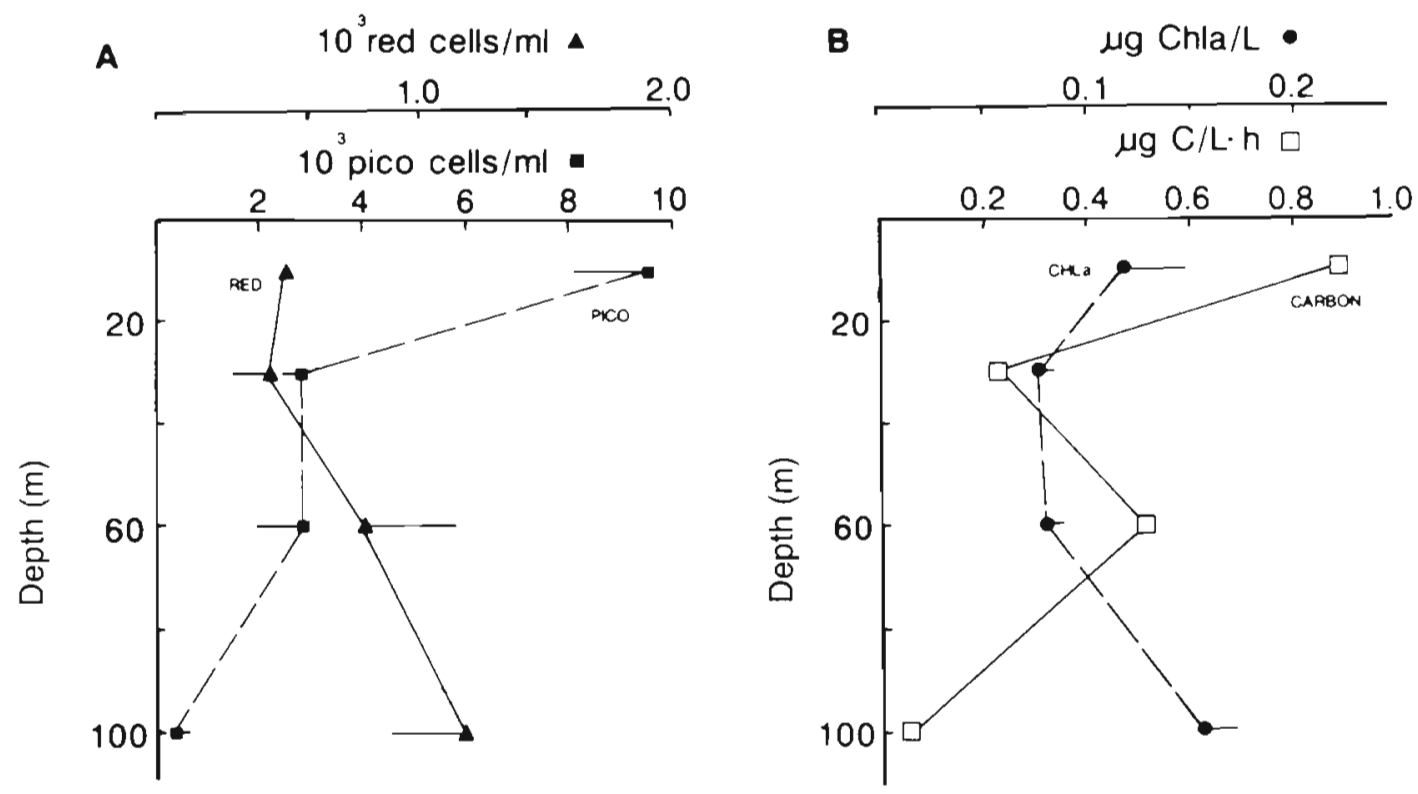

ng rbcL mRNA /L
or ng rbcL DNA/L

$\mu \mathrm{g} \mathrm{C/ \mu g} \mathrm{Chla \cdot h} \Delta$
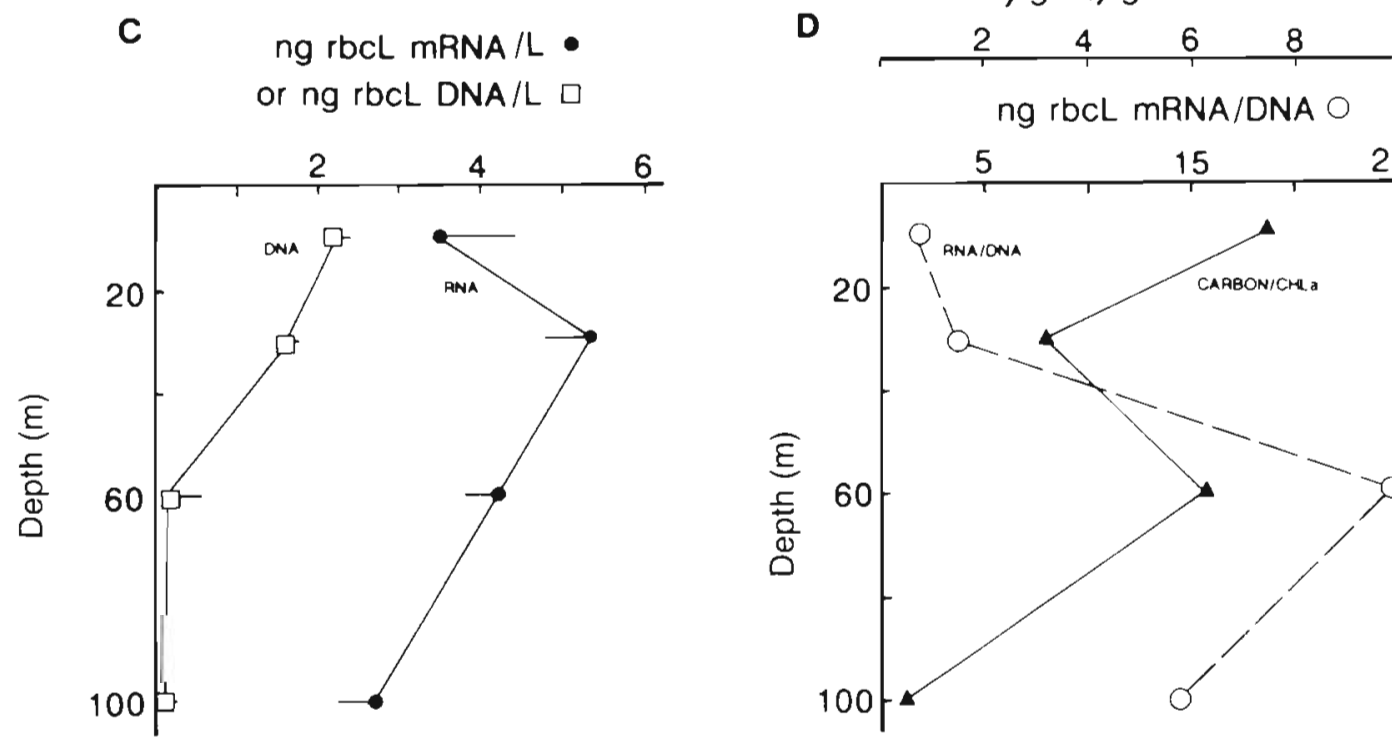

\section{ng $\mathrm{rbcL}$ MRNA/DNA O}

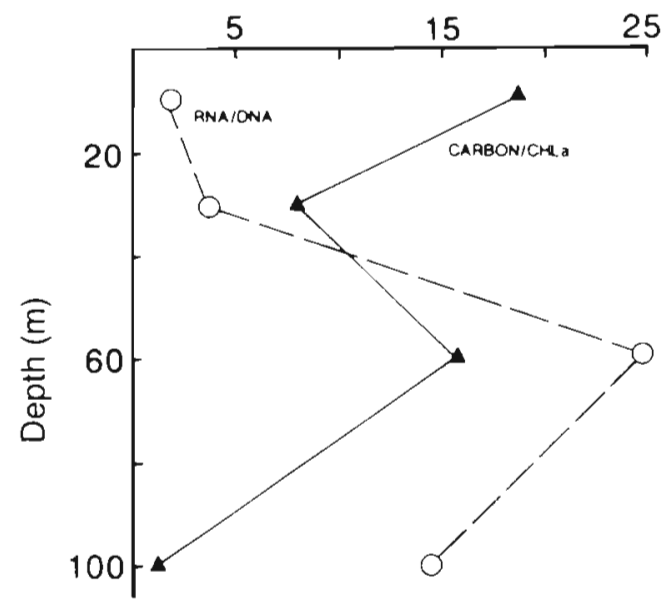

Fig. 6. Vertical profiles ( 1 SD) of $r b c L$ mRNA and related parameters for the Gulf of Mexico offshore Stn 6 as shown in dot blots in Fig. 5

mRNA present for the following reasons. Each sample potentially contains a diverse phytoplankton assemblage which may contain a diversity of $r b c L$ genes. In oligotrophic waters, the phytoplankton biomass is dominated by chroocoid cyanobacteria and prochlorophytes while other larger phytoplankton are much less abundant. We would therefore expect that the $r b c L$ gene probe employed from Synechococcus PCC 6301 would be appropriate to detect these types of RuBPCase genes. Yet, diatoms dominate in temperate estuaries (Kennish 1986) and also bloom at certain times of the year in the open ocean (Sargasso Sea spring bloom; Hulbert et al. 1960, Siegel et al. 1990). The diatom Cylindrotheca sp. strain N1 (Hwang \& Tabita 1991) has been shown to contain a divergent $r b c L$ sequence from that of the cyanobacterial/green plant lineage. If diatoms were abundant an underestimation of the actual level of $r b c L$ gene expression for the phytoplankton community could have occurred, particularly in nearshore and estuarine environments.

It is also possible that an increased gene dose may play an important role in regulating levels of specific mRNAs by providing more template for cellular RNA polymerases. Increases in gene dose are an important 


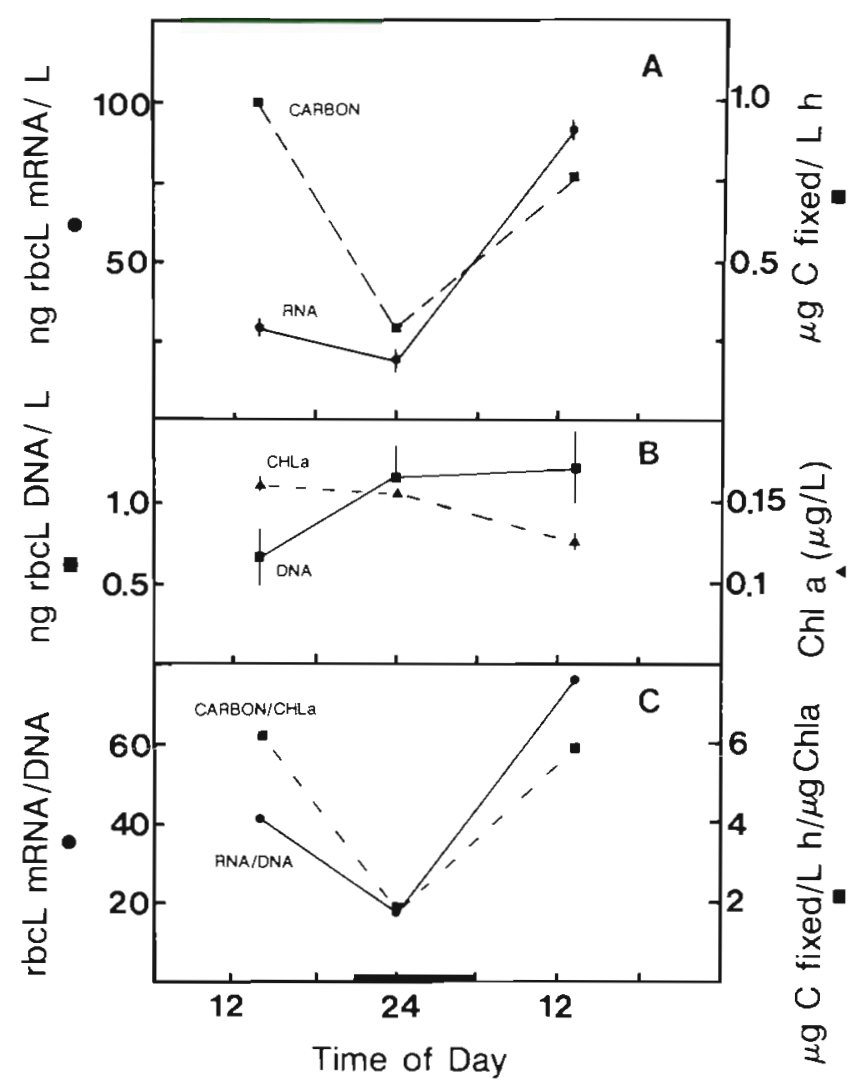

Fig. 7. Diel variations in $r b c L$ mRNA and related parameters for phytoplankton collected from Stn 3 and incubated in a tank. (A) Activity parameters of carbon fixation and mRNA. (B) Biomass parameters, chl a and DNA. (C) Biomass-normalized phytoplankton activities

mechanism that bacteria use to adapt to antibiotic and heavy metal stresses (Nordstrom et al. 1972, Phillippidis et al, 1991). This form of regulation of $r b c L$ expression occurs in the pea plant Pisum sativum. In this case, increases in $r b c L$ mRNA during illumination were partially the result of transcriptional acitivation of the $r b c L$ gene and an increase in the number of large subunit genes (Sasaki et al. 1984). For phytoplankton, studies of variations in $r b c L$ gene dosage have been limited to Chlamydomonas reinhardtii. In this alga reductions in the number of chloroplast genomes caused a dramatic reduction in $r b c L$ mRNA levels, yet RuBPCase protein synthesis remained unaffected (Hosler et al. 1989). This suggests that posttranscriptional mechanisms play a important role in regulating $r b c L$ gene expression in this organism.

In studies with marine Synechococcus sp., increases in RuBPCase activity have been potentially attributed to increases in RuBPCase gene copies, possibly resulting in increased mRNA levels (Karagouni et al. 1990). Binder \& Chisholm (1991) found that several marine Synechococcus isolates (WH8101, WH8103, and

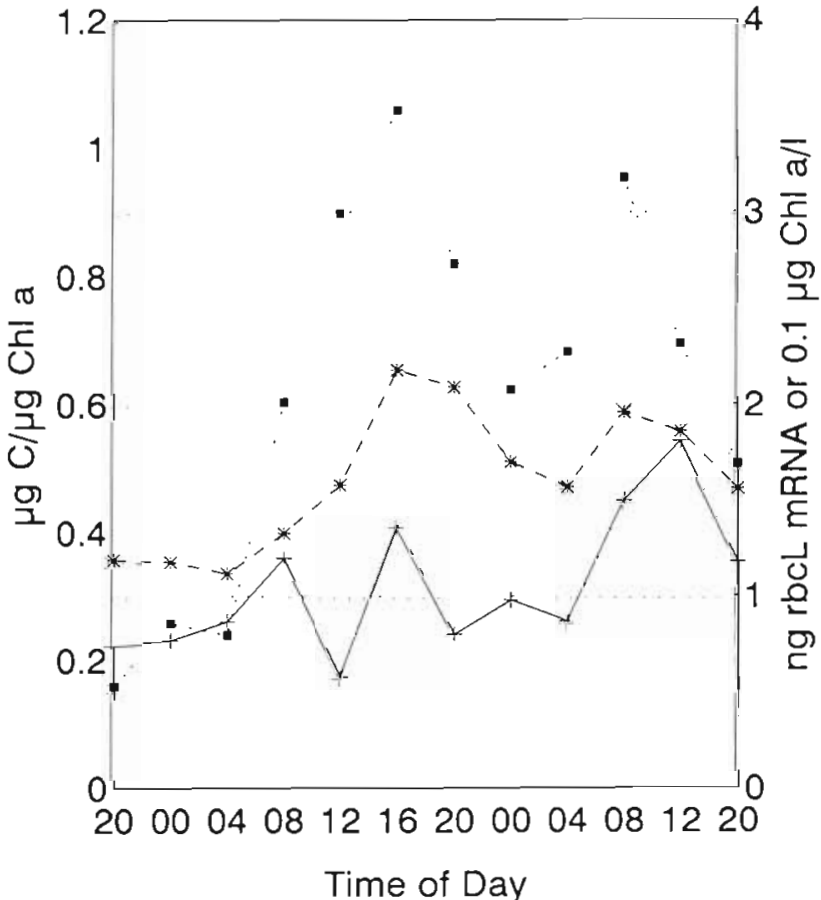

$$
\begin{aligned}
& \text { + rbcl mRNA } \\
& \text { * Chlorophyll a } \\
& \text { - Carbon fixation }
\end{aligned}
$$

Fig. 8. Diel variation of $r b c L$ expression, chl a in surface waters and carbon fixation for natural phytoplankton population in the Bahamas

WH7805) contained only 1 or 2 genome equivalents per cell, consistent with the slow growth of these forms. Alternatively, WH7803 was found to have up to 6 genome equivalents per cell. Such variations in genome content are probably the result of differences in growth rate and are probably not a mechanism for $r b c L$ regulation in the picocyanobacteria. In contrast to Synechococcus-like organisms, which may be an order of magnitude more abundant, the eucaryotic phototrophs may contain multiple copies of $r b c L$. In the eucaryotic algae there is significant variation in copies of coding loci per cell with the total number of chloroplastic rbcL genes being as high as 50000 per cell (Newman \& Cattolico 1990).

In general, Synechococcus-like picocyanobacteria are found at high numbers in the mid $(50 \mathrm{~m})$ to deep $(100 \mathrm{~m})$ euphotic zone (Li \& Wood 1988) with smaller eucaryotic picoplankton and prochlorophytes at even greater depths ( $<1 \%$ isolume). In this study, however, autofluorescent cyanobacteria were present in greatest numbers at $10 \mathrm{~m}$ and decreased with depth. The number of red fluorescent cells increased with depth 
A

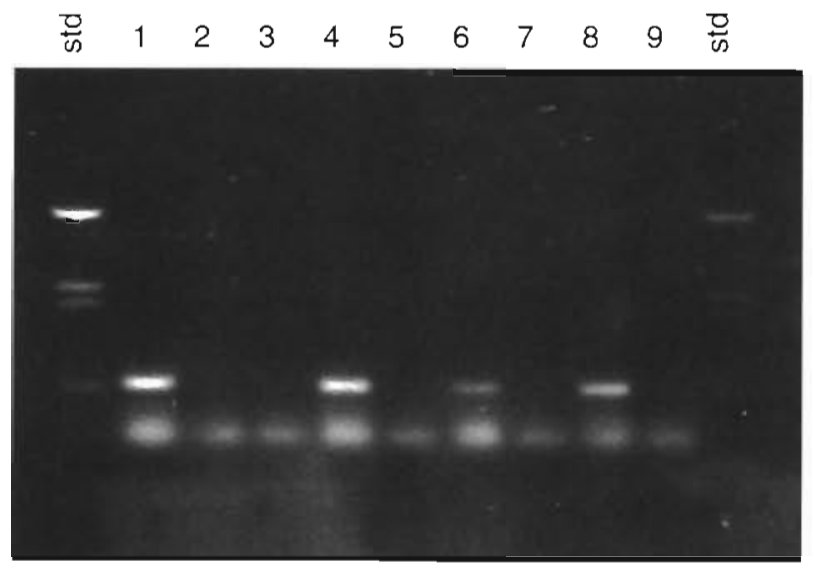

B

$\begin{array}{lllllllll}1 & 2 & 3 & 4 & 5 & 6 & 7 & 8 & 9\end{array}$

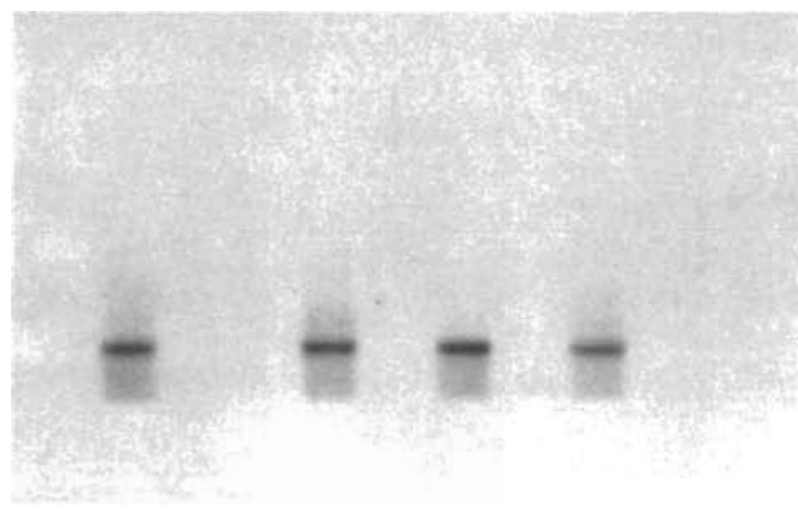

Fig. 9. Amplification of $r b c L$ mRNA from natural phytoplankton populations. (A) Gel electrophoresis ( 376 bp product indicated by arrow). (B) Southern transfer of gel in (A) and probed with the $r b c L$ gene probe. Lanes are - std: BstN1 pBR322 molecular weight standardi 1 : rbcL DNA PCR; 2: deionized water control for PCR; 3: PCR using purified $r b c L$ mRNA; 4: reverse transcriptase-linked PCR (RT-PCR) using rbcL mRNA; 5: PCR using an RNA extract from Bayboro Harbor; 6: RT-PCR using RNA extract from Bayboro Harbor; 7: PCR using RNA extracted from Synechococcus sp. PCC6301; 8: RT-PCR using RNA extracted from Synechococcus sp. PCC6301; 9: deionized water control for RT-PCR

and contributed to the deep chlorophyll maximum. The large picocyanobacterial population at $10 \mathrm{~m}$ was reflected in the largest levels of $\mathrm{CO}_{2}$ fixation, and the greatest amount of the $r b c L$ gene. The specific level of gene expression was not great in the surface waters because of the large population size. Additionally, chlorophyll specific carbon fixation $\left(P^{\mathrm{B}}\right)$ was great in this population, because of the apparent diminished chlorophyll contents of phytoplankton populations in surface waters. There was a subsurface $(60 \mathrm{~m})$ peak in carbon fixation, which was reflected in a high level of $P^{B}$ and the highest specific levels of $r b c L$ gene expression (gene expression/gene dose). This is indicative of a very active but smaller than surface photoautotrophic population, as reflected in cell counts, chl $a$ and rbcL gene content.

Diel fluctuations in phytoplankton carbon fixation rates and rbcL gene expression were observed in this study. Pichard \& Paul (1991) found that natural phytoplankton populations in the Dry Tortugas (Gulf of Mexico) and Synechococcus sp. PCC6301 in culture exhibited diel variations in the amount of $r b c L$ mRNA, with greater amounts in light periods and less in dark periods. In that study, as with the Bahamas diel in this study, one water mass was not captured, but rather sampled from the side of a ship at anchor. Therefore, the variation observed might have resulted from sampling different phytoplankton populations. By using open water natural populations incubated in an ondeck incubator the problem of sampling different phytoplankton populations was eliminated. Elevated levels of $r b c L$ mRNA corresponded to maximal rates of carbon fixation found during light periods. $r b c L$ DNA levels changed little, such that variations in levels of rbcL mRNA were not caused by changes in population size. In the case of natural populations in the Bahamas, changes in photosynthetic rates and rbcL mRNA levels varied with biomass (chl a), suggesting that changes in carbon fixation were caused by fluctuations in the size of the photosynthetic population in these samples.

Light stimulation of $r b c L$ transcription has been documented for some algal species. In the eucaryotic algae Cyanidium caldarium (Steinmuller \& Zetsche 1984) and Chlorogonium elongatum (Steinbib \& Zetsche 1986) the synthesis of the RuBPCase protein and mRNA was promoted by illumination. Yet transcription of the $r b c L-r b c S$ operon in a freshwater heterocystous cyanobacterium, Anabaena sp., appears to be constitutively expressed (Nierzwicki-Bauer et al. 1984). Also, variations in RuBPCase activity for tropical picoplankton were reflected in changes in picophytoplankton biomass as chl a (Glover 1989). RuBPCase enzyme activity from cell-free extracts showed no variation over light/dark periods while photosynthetic capacity varied in a diel manner for Gonyaulax polyedra.

Other photosynthetic genes exhibit light regulation of transcription in phytoplankton. Transcription of psbA, encoding the D1 protein of PS II in Synechococcus sp., occurs during periods of illumination (Schaffer \& Golden 1989). Similarly, the chlorophyll binding protein, cab, mRNA levels are elevated during the dark period in Dunaliella sp. (LaRoche et al. 1991).

It is also possible that the regulation of $r b c L$ may be an entrained circadian rhythm and not directly responsive to diel variations in light intensity. Cycles of light and dark have been used to entrain a circadian rhythm of photosynthetic oxygen evolution in a marine Synechococcus sp. (Mitsui et al. 1986) and expression 
of nitrogen fixation genes in a freshwater Synechococcus sp. (Huang et al. 1990). More importantly, circadian rhythmicities in photosynthetic activity have been observed for natural marine phytoplankton populations confined in tanks and held under constant illumination (Legendre et al. 1988). Studies on circadian rhythms in $r b c L$ gene expression have not been reported although such studies are currently under way.

The fact that $r b c L$ mRNA correlates well with carbon fixation rates does not exclude other enzymes from performing important functions in regulating carbon fixation. PEPCase is believed to play a role in phytoplankton carbon assimilation by the $\beta$-carboxylation of phosphoenolpyruvate. The theoretical maximum possible contribution by PEPCase to total carbon fixation in the light is $25 \%$ (Beardall 1989). During maximum rates of photosynthesis, PEPCase contributed only as much as $12.7 \%$ of the total photosynthesis (MortainBertrand et al. 1988). In fact, Smith et al. (1983) found that carbon fixation rates better correlated with RuBPCase activity than with PEPCase activity. Also, variations in levels of such enzymes as phosphoribulokinase, which regenerates the ribulose bisphosphate substrate, and carbonic anhydrase, which converts bicarbonate into carbon dioxide (RuBPCase substrate), may also have a role in regulating carbon fixation rates although no research was conducted to investigate this hypothesis.

The data suggest that natural marine phytoplankton exploit transcriptional regulation as a mechanism to regulate their carbon fixing ability. The data presented here represent a first attempt at understanding the molecular events regulating RuBPCase in these populations. However, additional studies will be necessary to determine the importance and universality of this regulatory mechanism in controlling phytoplankton carbon fixation. Thus, mRNA amplification and sequencing techniques will provide powerful tools necessary for determining the origin of $r b c L$ mRNA in natural populations as well as identifying the transcriptional activity of specific $r b c L$ genotypes.

Acknowledgements. This work was supported by both a Florida High Technology and Industry Council research grant and NSF grants 9022036 and 9216937 to J.H.P. We are grateful to F R. Tabita for supplying our lab with the rbcl gene probe. We also thank Wade Jeffrey for his assistance with the Bahamas diel study

\section{LITERATURE CITED}

Beardall, J. (1989). Photosynthesis and photorespiration in marine phytoplankton. Aquat. Bot. 34: 105-130

Becker-Andre, M., Hahlbrock, K. (1989). Absolute mRNA quantification using the polymerase chain reaction (PCR). A novel approach by a PCR aided transcript titration assay (PATTY). Nucleic Acid Res. 17:9437-9446
Binder, B. J., Chisholm, S. W. (1991). Cell cycle regulation in marine chroococcoid cyanobacteria. American Society of Limnology and Oceanography, 1991 Annual meeting, Halifax, Nova Scotia

Carpenter, E. J., Lively, J. S. (1980). Review of estimates of algal growth using $14 \mathrm{C}$-tracer techniques. In: Falkowski, P. G. (ed.) Primary productivity in the sea. Plenum Press, New York, p. 161-178

Chisholm, S. W. (1992). Phytoplankton size. In: Falkowski, P. G., Woodhead, A. (eds.) Primary productivity and biogeochemical cycles in the sea. Plenum Press, New York, p. 213-238

Chisholm, S. W., Olson, R. J., Zettler, E. R., Goericke, R., Waterbury, J. B., Welschmeyer, N. A. (1988). A novel freeliving prochlorophyte abundant in the oceanic euphotic zone. Nature 334: $340-343$

Colman, B. (1989). Photosynthetic carbon assimilation and the suppression of photorespiration in cyanobacteria. Aquat. Bot. 34: 211-231

Cote, R. (1984). ATCC media handbook, 1st edn. American Type Culture Collection, Rockville, MD

Deflaun, M. F., Paul, J. H. (1986). Hoechst 33258 staining of DNA in agarose gel electrophoresis. $J$, microbiol. Meth. 5: 265-270

Descolas-Gros, C., Fontugne, M. R. (1985). Carbon fixation in marine phytoplankton: stable carbon isotope ratios and carboxylase activities. Physiological and paleoclimatological aspects. Mar. Biol. 87: 1--6

Doty, M. S., Oguri, M. (1957). Evidence for a photosynthetic daily periodicity. Limnol. Oceanogr. 2: 37-40

Douglas, S., Durnford, D. G., Morden, C. W. (1990). Nucleotide sequence of the gene for the gene for the large subunit of ribulose-1,5-bisphosphate carboxylase/oxygenase from the chlorophyll c-containing alga, Cryptomonas $\Phi$ : evidence supporting the polyphyletic origin of plastids from purple bacteria. J. Phycol. 26: 500-508

Falkowski, P. G., LaRoche, J. (1991). Molecular biology in studies of ocean processes. Int. Rev. Cytol. 128: 261-303

Gelfand, D. H., White, T. J. (1990). Thermostable DNA polymerases. In: Innis, M. A., Gelfand, D. H., Sninsky, J. J., White, T. J. (eds.) PCR protocols: a guide to methods and applications. Academic Press, San Diego, p. 129-141

Glover, H. E. (1989). Ribulosebisphosphate carboxylase/oxygenase in marine organisms. Int. Rev. Cytol. 115: 67-138

Glover, H. E., Morris, I. (1979). Photosynthetic carboxylating enzymes in marine phytoplankton. Limnol. Oceanogr. 24: $510-519$

Holm-Hansen, O. Riemann, B. (1978). Chlorophyll a determination: improvements in methodology. Oikos 30:438-447

Hosler, J. P., Wurtz, E. A., Harris, E. H., Gillham, N. W., Boynton, J. E. (1989). Relationship between gene dosage and gene expression in the chloroplast of Chlamydomonas reinhardtii. Plant Physiol. 91. 648-655

Huang, T. C., Chow, T J. (1990). Characterization of the rhythmic nitrogen-fixing activity of Synechococcus sp. RF1 at the transcriptional level. Curr. Microbiol 20:23-26

Hulburt, E. M., Rhyther, J. H., Guillard, R. R. L. (1960). The phytoplankton of the Sargasso Sea off Bermuda. J. Cons. int. Explor. Mer 25: 115-127

Hwang, S. R., Tabita, F. R. (1991). Cotranscription, deduced primary structure, and expression of the chloroplastencoded $\mathrm{rbcL}$ and $\mathrm{rbcS}$ genes of the marine diatom Cylindrotheca sp. strain N1. J. biol. Chem. 266: 6271-6279

Itturiaga, R., Mitchell, B. G. (1986). Chroococcoid cyanobacteria: a significant component in the food web dynamics of the open ocean. Mar. Ecol. Prog. Ser. 28: 291-297

Karagouni, A. D., Boyle, S. A., Carr, N. G. (1990). The pres- 
ence and absence of inorganic carbon concentrating systems in unicellular cyanobacteria. FEMS Microbiol. Lett. 68: $137-142$

Kennish, M. J. (1986). Ecology of estuaries, Vol. II, Biological aspects. CRC Press, Boca Raton

Kostrzewa, M, Valentin, K., Maid, U., Radetzky, R., Zetsche, K. (1990). Structure of the rubisco operon form the multicellular red alga Antithamnion sp. Curr. Genet. 18: $465-469$

LaRoche, J., Mortain-Bertrand, A., Falkowski, P. G. (1991). Light intensity-induced changes in cab mRNA and lightharvesting complex II apoprotein levels in the unicellular chlorophyte Dunaliella tertiolecta. Plant Physiol. 97: $147-153$

Legendre, L., Demers, S., Garside, C., Haugen, E. M., Phinney, D. A., Shapiro, L. A., Therriault, J.-C., Yentsch, C. M. (1988). Circadian phtosynthetic activity of natural marine phytoplankton isolated in a tank. J. Plankton Res. 10: $1-6$

Li, W. K. W. Wood, M. (1988). Vertical distribution of North Atlantic ultraphytoplankton: analysis by flow cytometry and epifluorescence microscopy. Deep Sea Res. 35: $1615-1638$

Mitsui, A., Kumazawa, S., Takahashi, A., Ikemoto, H., Cao, S. Arai, T (1986). Strategy by which nitrogen-fixing unicellular cyanobacteria grow photoautotrophically. Nature 323: $720-722$

Morden, C. W., Golden, S. S. (1991). Sequence analysis and phyologenetic reconstruction of the genes encoding the large and small subunits of ribulose-1,5-bisphosphate carboxylase/oxygenase form the chlorophyll b-containing prokaryote Prochlorothrix hollandica. J. mclec. Evol. 32 379-395

Mortain-Bertrand, A., Descolas-Gros, C., Jupin, H. (1988). Pathway of dark inorganic carbon fixation in 2 species of diatoms: influence of light regime and regulator factors on diel variations. J. Plankton Res. 10: 199-217

Newman, S. M., Cattolico, R. A. (1987). Structural, functional and evolutionary analysis of ribulose-1,5-bisphosphate carboxylase from the chromophytic alga Olisthodiscus luteus. Plant Physiol. 84: 483-490

Newman, S. M., Cattolico, R. A. (1990). Ribulose bisphosphate carboxylase in algae: synthesis, enzymology and evolution. Photosynthesis Res. 26: 69-85

Nierzwicki-Bauer, S. A., Curtis, S. E., Haselkorn, R. (1984). Cotranscription of genes encoding the small and large subunits of ribulose-1,5-bisphosphate carboxylase in the cyanobacterium Anabaena 7120 . Proc. natl Acad. Sci. U.S. 81: 5961-5965

Nordstrom, K., Ingram, L. C, Lundback, A. (1972). Mutations in R factors of Escherichia coli causing an increased number of R-factor copies per chromosome. J. Bacteriol. 110: $562-569$

Orellana, M. V., Perry, M. J. (1992). An immunoprobe to measure Rubisco concentrations and maximal photosynthetic rates of individual phytoplankton cells. Limnol. Oceanogr. 37: $478-490$

Phillippidis, G. P., Malmberg, L. H., Hu, W. S., Schottel, J. L. (1991). Effect of gene amplification on mercuric ion reduction activity of Escherichia coli. Appl. environ. Microbiol. 57: $3558-3564$

Pichard, S. L., Paul, J. H. (1991). Detection of gene expression in genetically engineered microorganisms and natural phytoplankton populations in the marine environment by mRNA analysis. Appl. environ. Microbiol. 51: 1721-1727

Pichard, S. L., Paul, J. H. (1993). Gene expression per gene dose: a specific measure of gene expression in aquatic microorganisms. Appl. environ. Microbiol. 59: 451-457

Prezelin, B. B., Glover, H. E., L. Campbell. (1987). Effects of light intensity and nutrient availability on diel patterns of cell metabolism and growth in populations of Synechococcus sp. Mar. Biol. 95: 469-480

Sambrook, J., Fritsch, E. F., Maniatis, T (1989). Molecular cloning: a laboratory manual, 2nd edn. Cold Spring Harbor Laboratory Press, Cold Spring Harbor, NY

Sasaki, Y., Tomoda, Y., Kamikubo, T. (1984). Light regulates the gene expression of ribulose bisphosphate carboxylase at the levels of transcription and gene dosage in greening pea leaves. FEBS Lett. 173: 31-34

Schaffer, M. R., Golden, S. S. (1989). Differential expression of members of a cyanobacterial psbA gene family in response to light. J. Bacteriol. 171: 3973-3981

Siegel, D. A., Iturriaga, R., Bidigare, R. R., Smith, R. C., Pak, H., Dickey, T. D., Marra, J., Baker, K. S. (1990). Meridional variations of the springtime phytoplankton community in the Sargasso Sea. J. mar. Res. 48: 379-412

Smith, J. C., Platt, T., Harrison, W. G. (1983). Photoadaptation of carboxylating enzymes and photosynthesis during a spring bloom. Prog. Oceanogr 12: 425-459

Steinbib, H. J., Zetsche, K. (1986). Light and metabolite regulation of the synthesis of ribulose-1,5-bisphosphate carboxylase/oxygenase and the corresponding mRNAs in the unicellular alga Chlorogonium. Planta 167: 575-581

Steinmuller, K., Zetsche, K. (1984). Photo- and metabolite regulation of ribulose bisphosphate carboxylase/oxygenase and the phycobiliproteins in the alga Cyanidium caldarium. Plant Physiol. 76: 935-939

Strickland, J. D. H., Parsons, T R. (1968). A manual of sea water analysis, 2nd edn. Bull. Fish. Res. Bd Can. 125: $1-311$

Takahashi, M., Hori, T (1984). Abundance of picophytoplankton in the subsurface maximum layer in subtropical and tropical waters. Mar. Biol. 79: 177-186

Vargo, G. A. (1984). Growth rates of natural populations of marine diatoms as determined in cage cultures. In: HolmHansen, O., Bolis, L., Gillus, R. (eds.) Lecture notes in coastal and estuarine studies no. 8. Marine phytoplankton and productivity. Springer-Verlag, Berlin, p. 113-128

Vernet, M., Mitchell, B. G., Holm-Hansen, O. (1990). Adaptation of Synechococcus in situ determined by variability in intracellular phycoerythrin-543 at a coastal station off the Southern California coast, USA. Mar. Ecol. Prog. Ser. 63: $9-16$

Wang, D. H., Willis, D. L., Loveland, W. D. (1975). Radiotracer methodology in the biological, environmental, and physical science. Prentice-Hall, Englewood Cliffs

Waterbury, J. B., Watson, S. W., Valois, F. W., Franks, D. G. (1986). Biological and ecological characterization of the marine unicellular cyanobacterium Synechococcus. Can. Bull. Fish. Aquat. Sci 214: 71-120

Wilkerson, F. P., Dugdale, R. C. (1987). The use of large shipboard barrels and drifters to study the effects of coastal upwelling on phytoplankton dynamics. Limnol. Oceanogr. 32: $368-382$

Zar, J. H. (1984). Biostatistical analysis, 2nd edn. PrenticeHall, Englewood Cliffs
This article was presented by S. Y. Newell, Sapelo Island, Georgia, USA 